\title{
Agrarian Reforms in Indonesia: A Pleasure
}

\author{
FX Sumarja ${ }^{1}$, Ade Arif Firmansyah ${ }^{2}$, Pradipta Wijonugroho ${ }^{3}$ \\ \{franciscus.sumarja@fh.unila.ac.id ${ }^{1}$, ade.firmansyah@fh.unila.ac.id ${ }^{2}$, diptawijo@hotmail.com ${ }^{3}$ \} \\ Law Facultyof Universitas Lampung, Lampung, Indonesia ${ }^{1}$, Law Facultyof Universitas Lampung, \\ Lampung, Indonesia ${ }^{2}$, Law Facultyof Universitas Lampung, Lampung, Indonesia ${ }^{3}$
}

\begin{abstract}
Basically the land belongs to the Indonesian people. The state as the incarnation of the people only has the right to regulate its use in order to pursue common prosperity. Reorganization of land ownership and control as well as legal relations related to land exploitation in realizing equal distribution of prosperity and justice, is not balanced in implementation and only focuses on land redistribution / legalization of landless farmers (landless farmers), without any supporting policies another. It should be followed by other policies that follow, such as policies for opening new agricultural lands, efforts to increase productivity, policies on prices for agricultural products that benefit farmers, providing light credit, policies on low input prices, guidance and training for farmers, and marketing efforts for agricultural products.
\end{abstract}

Keywords: Farmers, Redistribution, Prosperity, Co-Policy

\section{Introduction}

The highest and most basic national land law politics as stated in the 4th paragraph of the Preamble of the 1945 Constitution has emphasized that the formation of the Indonesian State Government is to protect the entire Indonesian nation and all Indonesian bloodsheds and to advance the general welfare. The realization of such legal politics gave birth to the provisions of Article 33 paragraph (3) of the 1945 Constitution, that the land and water and natural resources contained therein are controlled by the State and used for the greatest prosperity of the people. Furthermore, this law politics is elaborated in various development policies and laws and regulations related to control, ownership and use of land.

Mohammad Hatta expressed his thoughts on the prosperity/welfare of the people, at the time of the drafting of the 1945 Constitution, including:

1) Indonesians live helping each other.

2) Every Indonesian person has the right to work and get a decent living for humans. The government bears the minimum basic life for a person.

3) The economy is structured as a joint venture, on a collective basis.

4) The production branch which controls the lives of many people, is controlled by the government.

5) Land belongs to the community, an individual has the right to use as much land as is necessary for him and his family.

6) One person's property must not be another's means of oppression.

7) The poor and poor are looked after by the Government.[1]

Moh. Hatta enriched the content of the provisions of Article 33 (3) of the 1945 Constitution of the Republic of Indonesia, and was manifested in Law No. 5 of 1960 concerning Basic Agrarian Principles (UUPA). The UUPA not only contains provisions regarding reform of Agrarian Law, but also contains other problems and their solutions. The 
solution to other problems in the formation of UUPA, is Indonesian Agrarian Reform. The birth of UUPA and Agrarian Reform Indonesia is aimed at creating a just and prosperous society based on Pancasila. Agrarian Reform Indonesia includes five programs, namely:

1) Agrarian law reform,

2) The abolition of foreign rights and colonial concessions to land,

3) A gradual end to feudal exploitation,

4) Reform of land ownership and control, as well as legal relations, and

5) Planning of supplies, allotment of the earth, water and natural resources contained and their planned use in accordance with their carrying capacity and capacity.[2]

The fourth of the five programs became known as the land reform program.

Long before the birth of the UUPA, Moh. Hatta[3] reminded in a speech in 1946, that in principle, land should be seen as a means or factor of production for common prosperity, not for the benefit of individuals, which in the end could lead to the accumulation of land tenure in a handful/community group. Accumulated land tenure can oppress other groups of people. Hatta said that no one should use the land as a tool to oppress other groups of society, because this is against the basis of a just economy as aspired by the Indonesian people.

Further said by Moh. Hatta, that basically land belongs to the Indonesian people. The state which is the incarnation of the people only has the right to regulate its use in order to pursue common prosperity. The UUPA put more emphasis on agricultural land for the peasant people, so that September 24 was commemorated as "farmer's day" for 10 years, starting from 1963 to 1972, through Presidential Decree No. 169/1963 dated 26 August 1963.

In connection with Moh. Hatta said, the government should not be passive but must actively carry out efforts to build the welfare of its people by regulating economic and social life,[4] including implementing agrarian reform.

\section{Method}

This research paper is wrote on a normative legal research corridor. with an approach in the form of a statutory and conceptual approach.[9] The research data used in this study relies on secondary data. the analysis was done qualitatively and described descriptively.

\section{Literature Review}

In line with what Moh. Hatta, that a prosperous agrarian country is a country that implements an equitable distribution of land tenure. The UUPA confirms it in the provisions of Article 7 and Article 17, that land ownership and control that exceeds boundaries is prohibited. So that the government issued a land reform policy as stipulated in Law no. 5 of 1960 concerning the Determination of Agricultural Land Areas. Unfortunately, however, at the practical level it is still far from being expected.The spirit of collectivity, mutual cooperation and concern for the weak who do not have access to the natural resources built by the founders of the nation seem to have disappeared.

The community of the weak and marginalized (peasants and agricultural laborers) after all they are part of this nation that does not deserve to be amputated just to fulfill the interests of development. In fact, it seems that the Indonesian people are still reluctant to learn from other nations. Agrarian reform in several socialist and capitalist countries that have actually 
implemented the concept of Agrarian Reform (RA) has consistently and shown its success, such as Russia (809 million ha), Canada (310 million ha), Brazil (478 million ha) and Congo (134 million ha). They run and implementing RA based on the spirit of justice, discipline and openness and eradicate poverty and build economic independence for local communities.[10]

Implementing RA can be understood as a revision and prevention of permanent land accumulation, or in more popular meaning is to distributing and redistributing land in particular.[5] The purpose of this agrarian reform is to achieve justice in the agrarian structure.[6] And also, the agrarian reform could increase social economic status of the receivers.[7] For example, with a significant land area of the reform occurring in forests, the changes are supposed to improve the livelihoods of forest dependent communities, protect forests, and mitigate climate change.[8]

Indonesia, which is one of the countries with the largest tropical forest area in the world along with Brazil and Congo, has since the beginning had a strong commitment to implementing the concept of agrarian reform. However, in its journey, due to the influence of deideologization, depoliticization and political deconstruction of land resource management by various interest groups who are symbiotic with various state actors, it has resulted in inconsistency in the government in implementing agrarian reform as a whole, pseudo agrarian reform. So that what emerges is not welfare, but the spread of land tenure conflicts both outside and inside state forest areas.

Agrarian politics changed completely during the New Order era, by replacing the equity paradigm with the growth paradigm. This means that during the Old Order era, agrarian development focused on equal access to land for the Indonesian people, while in the New Order it focused on economic growth without being followed by equal access to land.[11] The land reform program launched by President Soekarno in 1961, failed not only because of the political changes in 1965, but also due to the emphasis on land redistribution and distribution, without being followed by access to reforms. This means that Indonesia's five agrarian reform programs [2] that have been established by the UUPA, especially in reforming land ownership and control as well as legal relations related to land exploitation in realizing equitable prosperity and justice, are not balanced in implementation and only focus on granting land to smallholders. (peasants without land ownership), without any other supporting policies.

The granting of land to farmers should be followed by other policies, such as policies for opening new agricultural lands, efforts to increase productivity, policies on prices for agricultural products that benefit farmers, providing light credit, policies on low input prices, guidance and training for farmers, and marketing efforts for agricultural products, without all of these it is impossible for land reform to be successful.

In fact, during the New Order era, the land reform program also still existed.[2] It's just that the implementation is far more resonant / powerful to provide land for big companies than for farmers. It is like the land reform program for farmers is implemented using the pedicab mode of transportation, while the programs provided for the benefit of large companies, both in the fields of plantation, agriculture, industry, and forest management use airplane transportation modes.

In such a context, it is clear from the carrying capacity and speed that it is certainly the company that benefits, compared to farmers / tenants. Till farmers have still not been able to get their agricultural land. Not only that, what is even more concerning is that more and more farmers are losing their agricultural land because they are forced to give it up for development. 


\section{Results and Discussion}

The number of smallholders (farmers who control less than 0.5 ha of land per family) is increasing. If in 1993 the number of smallholder farmers nationally was 10.9 million, in SP 2003, that figure rose to 13.7 million families, an increase of 3.8 million families in 10 years. On the island of Java, out of every four farmers, three are small farmers.[12] In addition, data from the Central Statistics Agency (BPS) shows that, in 2010, the area of rice farming in Indonesia was only 12.870 million ha, shrinking $0.1 \%$ from 12.883 million ha in the previous year. Overall, the area of agricultural land, including non-rice, in 2010 was estimated at 19.814 million ha, a $13 \%$ decrease compared to 2009 which reached 19.853 million ha. This condition continues to worsen the life of farmers.[13]

In addition to the increasing number of smallholders, the number of farmer households is decreasing. It is evident from the results of the 2013 agricultural census (SP), showing that from year to year the number of farmer households decreases by an average of $1.75 \%$ each year. In 2003 , there were $31,170,100$ farmer households to $26,126,200$ in 2013 , so that over the last 10 years the number of farmer households decreased by 4,043,900.[14] On the other hand, the number of agricultural companies with legal status has increased, if in 2003 it amounted to 4,011 to 5,486 in 2013.

The Reformation Era, which has reached 17 years when marked by a change in the government system from the New Order era, still has many questions. The democratization of farmers and agriculture through various pro-capitalist food and land import policies and the reproduction of the cultural junk food habit is what BudimanSudjatmiko termed as an alienated development. This understanding shows that the perspective or mental attitude of a nation towards farmers and agriculture will determine whether the nation's civilization or culture will develop or not.

Likewise South Korea or Taiwan. Taiwan is far behind Indonesia's pre-World War II position, while South Korea is roughly the same as Indonesia. The perspective or mental attitude of the two countries towards agriculture and its farmers is quite extraordinary. The two countries interpreted land reform as sharia or the behavior of eliminating colonial symbols. The symbol of colonialism is injustice. In the situation of agrarian society which was still prevailing at that time, injustice must have existed in the distribution of land. Even worse, this injustice was compounded with feudalism. Therefore, the two nations completed the first Shari'a, namely land reform, before entering into a more profound and widespread behavior.[10]

Apart from land reform, Japan, South Korea and Taiwan are very visible in their siding with agriculture. The fruit is that they become developed countries. The result is that the per capita income of Taiwan, Japan, South Korea and Indonesia in 2012 according to the IMF in terms of Purchasing Power Parity (PPP) is US \$ 38,749, US \$ 36,266, US \$ 32,272, and US \$ 4,977 , respectively. As it turns out, Taiwan's income is 7.78 times Indonesia's. It seems that a positive change in the mental attitude or perspective of the Indonesian people towards farmers and agriculture is not yet like the three countries.

Even after the UUPA was 57 years old, there was still tremendous imbalance in control of agrarian resources. Joyo Winoto, when he was Head of the National Land Agency (BPN), said that 56 percent of our national assets are controlled by only 0.2 percent of the population. Of the national assets under control, 87 percent is in the form of land. RusmanHeriawan, Deputy Minister of Agriculture, once said that 40 million farmer families control an average of 0.3 hectares of land. The next question is, are we going to let the gaps that hurt the conscience of 
the peasants and the poor get sharper? Is this nation powerless to overhaul it? Who should remodel it, when and how to remodel it?

The number of poor people in Lampung based on the results of the National SocioEconomic Survey (Susenas) September 2016 reached 1.14 million people (13.86 percent). This number is less than that of March 2016 which reached 1.17 million people (14.29 percent).[15] In general, the poor are a group of landless farmer families who try to get their livelihoods from farming.[16]

The nine priority programs or NawaCita formulated by the Jokowi-JK pair, there are several things related to agrarian, namely point number 5 about improving the quality of life of the people through the Indonesia work program and prosperous Indonesia by encouraging land reform and land ownership programs covering 9 million hectares. As a fulfillment of its promise, the Government has prepared a land area of 9.1 million hectares for the targeted asset redistribution and agrarian reform program for the people. The land covering an area of about 9.1 million hectares, spread across Sumatra, Kalimantan, Sulawesi and Papua, is to be used as agricultural land, plantations and housing. "From an area of approximately 9.1 million hectares, currently only 4.5 million hectares have begun to be processed for the agrarian reform program,"[17]

According to Rachman, some of the root problems that must be resolved to carry out agrarian reform are: (1) There is no policy to provide tenure security for access to lands / natural resources / areas managed by communities, including access in state forest areas, 2) Domination and expansion of giant business entities in the extractive industry, plantation and forestry production, and conservation, 3) Instrumentation of government agencies as "land acquisition agencies" through rights/permit/ license granting regimes over land and resources land, 4) UUPA which was originally placed as an umbrella, in practice it was narrowed down to only managing non-forest areas (around 33.3\% of the Republic of Indonesia's land area), and its principles were ignored. Legislations concerning land/forestry/ other natural resources are overlapping and contradicting one another, 5) Customary laws that apply among the people are ignored or their enforcement is nullified by agrarian, forestry and mining laws, and 6) Increasingly, institutional sectoralism, systems, mechanisms and administration regulating land/forestry/other natural resources.[10]

However, according to the author's opinion, it does not mean that agrarian reform is waiting for the solution to the root of the problem. Agrarian reform can still be carried out, while at the same time trying to solve the root of the problem.

Steps taken by the government to be able to allocate land for the poor, namely land originating from conversion forests, and other land which according to land law can be designated for the benefit of the people. Land originating from conversion forest is clear, that it depends on the Ministry of Forestry and the Environment whether to release it or not. If the Ministry wants to release, it means that the land is there and ready to be redistributed. Then which land is meant by "other land". Of course, when talking about land reform, the land that can be redistributed is state land. State land that can be used as the object of land reform is absentee land, maximum excess land, former self-governing land, and land directly controlled by the state which will be affirmed by the Minister of Agrarian Affairs (now the Ministry of Agrarian Affairs and Spatial Planning / Ka.BPN-RI). The final definition of land includes land that has been voluntarily handed over by the owner to the state, land rights revoked by the state, land that no longer has a right holder, abandoned land, embossed land,[18] and state land based on the provisions of Article 21 paragraph (3) and Article 26 paragraph (2) UUPA.

With the issuance of Perpres 86/2018 concerning Agrarian Reform, the government's commitment to providing justice and access to land for the poor is even stronger. It is said 
firmly, because: a) This Presidential Regulation is an operational implementation of the operational; b) become an overarching regulation for various sectoral regulations; c) realizing an equal distribution of land tenure, ownership, use and utilization structures; d) its implementation involves all Ministries / Agencies to work synergistically; and e) open space for direct community involvement/participation in the entire process of implementing agrarian reform.

Agrarian Reform is implemented through the stages of structuring assets and structuring access. Arrangement of assets is the basis for structuring access. Asset management is carried out by means of land redistribution and asset legalization or land registration. Access arrangement is implemented in order to increase economies of scale, added value, and encourage entrepreneurial innovation on the subject of agrarian reform. Land redistribution can be carried out if the object of reform is clear. Therefore, planning to determine object \&subject becomes an important issue going forward, especially ensuring the implementation of agrarian reform is right on target. The Agrarian Reform Consortium and other civil society organizations have recommended priority areas for Agrarian Reform (LPRA) covering an area of 655,343 hectares, in 446 locations, in 20 provinces in Indonesia. The suggestions from below are an attempt to prevent misdirection.

There are 11 types of Land for Agrarian Reform Objects (TORA) according to Presidential Decree 86 of 2018, namely:

1) TORA from HGU and HGB that have been used up must be ascertained in priority for the subject of agrarian reform, not companies or those previously controlling;

2) Allocation of $20 \%$ of HGU which is converted into HGB due to changes in spatial planning designation;

3) Allocation of $20 \%$ of HGU from the area of State Land granted to HGU holders in the process of granting, renewing or renewing their rights;

4) TORA from the release of forest areas, it must be ensured that there is a joint process with the local community to review the boundaries of forest area designations and land controlled by the community.

5) State land which is formerly abandoned land which is utilized for the benefit of the community and the state through Agrarian Reform;

6) Land resulting from the settlement of Agrarian Disputes and Conflicts;

7) Ex-mining land that is outside the forest area;

8) Raised land;

9) Maximum excess land, absentee land, and swapraja/ex swapraja land that are still available;

10) Land that meets the requirements for strengthening people's rights to land;

11) Land ex-erpacht rights, ex-private land and ex-eigendom land with an area of more than 10 (ten) bauw which are still available.

In addition to the aforementioned lands, there are actually still potential objects that can be used as objects of TORA, namely: First, lands whose rights holders do not meet the requirements as the subject of rights, and they have not transferred their rights to the subject of rights who have the right in due time, or they has not made changes to rights in accordance with the provisions, such as the provisions of Article 21 UUPA. Second, private land which is transferred to foreigners in disguise, for example by means of a guise/nominee/trustee, which is regulated in Article 26 paragraph (2) UUPA. It seems that land like this has not yet become the attention of the Government or the Ministry of Agrarian and Spatial Planning/Head of the National Land Development Agency-RI.[19] 
After determining the object of agrarian reform, the next stage is to determine the subject so that it is right on target. The subjects of agrarian reform based on priority are local residents, agricultural laborers, smallholders, farmers, the poor, and other subjects. This has been regulated in Article 12 of Perpres 86/2018, which includes the subjects of agrarian reform: individuals, groups and legal entities, especially cooperatives. Individual subjects are at least 18 years old and must be synergized with Presidential Instruction 2/2018 on PTSL by ensuring the maximum area of each recipient or subject of reform. Meanwhile, the group subject must be synergized with Permen ATR / BPN Number 10 of 2016 concerning Communal Rights by ensuring that all tenure relations, especially indigenous people, can be accommodated.

Legal entities must be prioritized for cooperatives and BUMDes, in line with Law 6/2014 on Villages. The cooperative must be ensured that it is established and owned by a peasant organization, not owned by a few people. Moreover, in determining the subject of agrarian reform, we must adhere to the principle of priority. The principle of subject priority is attachment to the land, the "closer" it is, it gets top priority. Subject priorities can refer to PP 224/1961 and PP 41/1964.

The implementation of agrarian reform based on Perpres 86/2018 will encounter several challenges, including:

1) There are attempts to refuse HGU holders.

2) Public expectations are very high, while GTRA has experienced a lot of pressure.

3) Domination and expansion of giant business entities in extractive industries, plantation and forestry production, and conservation.

4) Instrumentation of government agencies as "land acquisition agencies" through rights / permits / license granting regimes over land and land resources.

5) There are still laws and regulations regarding land / forestry / other SDA which are overlapping and contradictory to one another.

6) The customary laws that apply in the community are neglected or their enforcement is nullified by the agrarian, forestry and mining laws.

7) Institutional sectoralism, systems, mechanisms and administration regulating land / forestry / other natural resources which are still difficult to eliminate.

\section{Conclusion}

1) Given the imbalance in land ownership and control is still occurring and increasingly sharp, agrarian reform is appropriate, urgent and absolute to be implemented, until the development goals are achieved, namely a just and prosperous society.

2) Realizing a just and prosperous society, requiring partiality and a change in the attitude of the Indonesian nation and state towards farmers and agriculture, they are no longer a lower class. They must be elevated in rank according to their capacity as foodstuff providers for mankind.

3) The Ministry of Agrarian Affairs and Spatial Planning / BPN RI cannot work alone in carrying out agrarian reform, there needs to be a joint commitment in implementing Presidential Regulation 86/2018. 


\section{References}

[1] R. A. Kusuma, Lahirnya Undang-Undang Dasar 1945. Jakarta: FHUI, 2009.

[2] B. Harsono, Hukum Agraria Indonesia: Sejarah Pembentukan Undang-Undang Pokok Agraria, Isi dan Pelaksanaannya. Jakarta: Djambatan, 2008.

[3] E. Suhendar and I. Kasim, Tanah sebagai komoditas, kajian kritis atas kebijakan pertanahan orde baru. Jakarta: Lembaga Studi Advokasi Masyarakat (ELSAM), 1996.

[4] M. M. MD, Demokrasi dan Konstitusi di Indonesia- Studi Tentang Interaksi Politik dan Kehidupan Ketatanegaraan. Jakarta: Rineka Cipta, 2003.

[5] S. M. P. Tjondronegoro, "A Brief Quarter Century Overview of Indonesia's Agrarian Policies." http://pse.litbang.pertanian.go.id/ind/pdffiles/PROS_ESCAP_PSEKP_TJONDRO.pdf (accessed Oct. 01, 2020).

[6] S. Widodo, "A critical review of indonesia's agrarian reform policy," J. Reg. City Plan., vol. 28, no. 3, pp. 204-218, 2017, doi: 10.5614/jrcp.2017.28.3.4.

[7] M. Sadyohutomo, "The benefits of an agrarian reform model in Indonesia," IOP Conf. Ser. Earth Environ. Sci., vol. 202, no. 1, 2018, doi: 10.1088/1755-1315/202/1/012030.

[8] I. A. P. Resosudarmo et al., "Indonesia's land reform: Implications for local livelihoods and climate change," For. Policy Econ., vol. 108, no. August 2018, p. 101903, 2019, doi: 10.1016/j.forpol.2019.04.007.

[9] P. M. Marzuki, Penelitian Hukum. Jakarta: Kencana Prenada Media Group, 2011.

[10] I. Hakim and L. R. Wibowo, Hutan Untuk Rakyat, Jalan Terjal Reforma Agraria Di Sektor Kehutanan. Yogyakarta: LkiS, 2014.

[11] Ismail Nurhasan, "Arah Politik Hukum Pertanahan Dan Perlindungan Kepemilikan Tanah Masyarakat," J. Rechts Vinding Media Pembin. Huk. Nas., 2012.

[12] "Sensus Pertanian 2013," 2013. http://hargajateng.org/sensus-pertanian-2013.html (accessed Jul. 27, 2013).

[13] F. Sumarja, Hak Atas Tanah Bagi Orang Asing, Suatu Tinjauan Politik Hukum dan Perlindungan Warga Negara Indonesia. Yogyakarta: STPN Press, 2015.

[14] "Laporan Bulanan Data Sosial Ekonomi Edisi Ke-40," 2013.

[15] B. P. Statistik, “Angka Kemiskinan Lampung, September 2016," 2017. https://lampung.bps.go.id/Brs/view/id/487 (accessed Aug. 23, 2017).

[16] F. Sumarja, "Chaos of Forest Resource Access Regulation: Study on Moro-Moro Farmers at Register 45 Lampung," 2017.

[17] N. (Secretary G. of the M. of A. A. and S. P. L. A. Marzuki, "Kembali ke Khittah Reforma Agraria," 2017. lampungpro.com (accessed Sep. 22, 2017).

[18] M. Shohibuddin and M. N. Salim, Pembentukan Kebijakan Reforma Agraria 2006-2007, Bunga Rampai Perdebatan. Yogyakarta: STPN Press, 2013.

[19] F. Sumarja, "Politik Hukum Larangan Kepemilikan tanah Hak Milik Oleh Orang Asing untuk Melindungi Warga Negara Indonesia," Universitas Diponegoro, 2015. 